\title{
Money Laundering and the African Court of Justice and Human and Peoples' Rights
}

\author{
CECILY ROSE
}

\section{INTRODUCTION}

The inclusion of money laundering within the jurisdiction of the African Court of Justice and Human and Peoples' Rights (African Court) is novel and innovative. ${ }^{1}$ But if the African Court eventually exercises its jurisdiction over the offence of money laundering, it would not, in fact, be the first international criminal court or tribunal to undertake financial investigations in connection with criminal prosecutions. One of the International Criminal Court's (ICC) earliest situations, in the Democratic Republic of the Congo (DRC), required it to investigate money laundering by armed groups and organized crime groups engaged in the exploitation of mineral resources in Ituri. $^{2}$ The ICC Prosecutor considered that the exploitation of natural resources in the region was, in part, fuelling the alleged atrocities, and that the international banking system was facilitating money laundering in this context. ${ }^{3}$ Even though the ICC lacked the capacity to charge individuals for money laundering itself, the Prosecutor viewed such financial investigations as, nevertheless, playing an important role in the prevention and prosecution of atrocities within the court's jurisdiction. ${ }^{4}$

The inclusion of the offence of money laundering in the African Court's Amended Protocol on the Statute of the African Court allows prosecutors at

1 African Union, Draft Protocol on Amendments to the Protocol on the Statute of the African Court of Justice and Human Rights, Exp/Min/IV/Rev.7 (May 2012), art. 28Ibis.

$=$ Second Assembly of States Parties to the Rome Statute of the International Criminal Court, Report of the Prosecutor of the ICC, Mr Luis Moreno-Ocampo, 8 September 2003, 3-4.

3 ICC Press Release, 'Communications Received by the Office of the Prosecutor of the ICC' (No.: pids.009.2003-EN), 16 July 2003, 3-4.

4 Ibid. 
the Court to go beyond the ICC's use of financial investigations in a supporting capacity. The African Court would not only be in a position to support the prosecution of other crimes through money laundering investigations, but it would also be able to bring charges against the accused for the very act of money laundering. This would bring a number of benefits. By prosecuting money laundering as well as corruption, the African Court would be able to highlight the detrimental impact of economic crimes, which can play a structural role in fuelling the perpetration of atrocities such as war crimes and crimes against humanity, as seen in the DRC. In addition, by virtue of the fact that the African Court, like the ICC, operates on the basis of the principle of complementarity, its jurisdiction over money laundering could also, at least in theory, have the effect of prompting more domestic law enforcement actions regarding money laundering. Convictions for money laundering at the African Court could also potentially facilitate the identification, freezing, and seizure of assets that may be repatriated or used for the purpose of reparations for victims.

But a number of significant obstacles, both jurisdictional and evidentiary, may stand in the way of successful prosecutions of money laundering at the African Court. From a jurisdictional standpoint, defence counsel can be expected to raise arguments about violations of the principle of nullum crimen sine lege on account of the absence of any customary international legal norm prohibiting money laundering. In addition, the narrow scope of the offence of money laundering, as set out in the Amended Protocol, would prevent prosecutors from bringing charges in any context other than corruption of a 'serious nature affecting the stability of a state, region or the Union'. ${ }^{5}$ Despite the fact that many other crimes within the African Court's jurisdiction can generate proceeds that are laundered, the Amended Protocol restricts the offence of money laundering to proceeds generated from serious forms of corruption. This means that acts of money laundering in connection with other crimes, besides serious, high-level corruption, would have to be prosecuted at the national level. Finally, not all of the possible preconditions for the exercise of jurisdiction by the African Court would be relevant or viable for the prosecution of money laundering, thus potentially further restricting the prosecutor's ability to bring charges for such conduct. ${ }^{6}$ Although the Court may, in theory, exercise its jurisdiction based on the nationality of victims as well as the effects of extraterritorial acts (the passive personality and protective

\footnotetext{
5 Amended Protocol, art. 28I(1) (chapeau).
}

6 Ibid., art. 46Ebis. 
principles, respectively), in practice these jurisdictional preconditions will not be workable in the money laundering context.

From an evidentiary perspective, complex financial investigations could be expected to strain or exceed the prosecution's human and financial resources. In addition, prosecutors conducting such investigations would likely be heavily dependent on cooperation not only from states parties, but also non-state parties with no legal obligation to comply with requests for assistance in obtaining evidence, freezing assets, etc. ${ }^{7}$ Because many major banking centres lie outside of Africa in non-states parties, the Court's inability to oblige cooperation may significantly impede its capacity to gather evidence. Moreover, some non-states parties may be reluctant, in the first place, to cooperate with investigations that could undermine their own domestic law enforcement efforts.

This chapter begins by explaining why prosecuting money laundering at the African Court would not only be novel, but could also be beneficial for the Court's exercise of criminal jurisdiction more broadly (Section 2). The following sections address the jurisdictional and evidentiary challenges that could arise during the course of investigations and prosecutions (Sections 3 and 4 ), before exploring the possibility that money laundering prosecutions could facilitate asset recovery and repatriation (Section 5).

\section{WHY PROSECUTE MONEY LAUNDERING AT THE AFRICAN COURT?}

Calls for international prosecution of money laundering have been relatively rare. But this does not necessarily mean that international courts could not or should not undertake prosecutions of this offence. In fact, financial investigations concerning money laundering have already been carried out by the Special Court for Sierra Leone and the ICC for various reasons other than bringing criminal charges. The international legal framework for combating money laundering has, however, always been premised on the notion that domestic courts are responsible for prosecuting the offence of money laundering. Various international instruments require or call on states to criminalize money laundering in their domestic legal systems, and to cooperate with other states in prosecuting offenders through extradition and mutual legal assistance. While numerous international treaties require states to criminalize money laundering, they do not actually create any international criminal liability for this offence. They assume that enforcement is a matter for domestic rather than international courts.

7 Ibid., art. $46 \mathrm{~L}$. 
The widespread domestic criminalization of money laundering began following the adoption of the 1988 United Nations Convention against Illicit Traffic in Narcotic Drugs and Psychotropic Substances (1988 Vienna Convention) as well as the 40 Recommendations of the Financial Action Task Force (FATF), which were first issued in 1990. ${ }^{8}$ Treaty provisions addressing money laundering have since multiplied, and expanded in scope, with the conclusion of the 2000 United Nations Convention against Transnational Organized Crime (UNTOC) and the 2003 United Nations Convention against Corruption (UNCAC), as well as a number of regional anti-corruption treaties, including the African Union Convention on Preventing and Combating Corruption (AU Convention). ${ }^{9}$ The 1988 Vienna Convention and the 1990 version of the FATF Recommendations were both narrow in scope in that they addressed money laundering in the sole context of drug trafficking, meaning that these instruments targeted the laundering of the proceeds of drug trafficking alone. But UNTOC and UNCAC include broader provisions on money laundering that call upon states to criminalize the laundering of the proceeds of 'the widest range of predicate offences'. ${ }^{10}$ At a minimum, states parties must establish as predicate offences the criminal offences set out in the Conventions themselves (eg organized crime, bribery, etc). ${ }^{11}$ Likewise, later versions of the FATF 40 Recommendations have also called on states to criminalize money laundering in relation to all serious offences. ${ }^{12}$

The Amended Protocol builds on the 1988 Vienna Convention, UNTOC, UNCAC, and the AU Convention on Preventing and Combating Corruption, but at the same time it also points anti-money laundering enforcement in a notably different direction. Moreover, it does so without the benefit of scholarly debate about the merits and drawbacks of this potential shift. The Amended Protocol builds on these treaties by adopting very similar language - Article

${ }^{8}$ United Nations Convention against Illicit Traffic in Narcotic Drugs and Psychotropic Substances (adopted 20 December 1988, entered into force 11 November 1990) 1582 UNTS 95; Financial Action Task Force, 'International Standards on Combating Money Laundering and the Financing of Terrorism and Proliferation: The FATF Recommendations' (February 2012).

9 United Nations Convention against Transnational Organized Crime (adopted 15 November 2000, entered into force 29 September 2003) 2225 UNTS 209; United Nations Convention against Corruption (adopted 11 December 2003, entered into force 14 December 2005) 2349 UNTS 41. The regional anti-corruption treaties include African Union Convention on Preventing and Combating Corruption (adopted 11 July 2003, entered into force 5 August 2006) (2004) 43 ILM 5; Inter-American Convention against Corruption (adopted on 29 March 1996, entered into force 6 March 1997) (1996) ILM 724.

${ }^{10}$ UNTOC art. 6(2)(a), UNCAC art. 23(2)(a).

${ }^{11}$ UNTOC art. 6(2)(b); UNCAC art. $23(2)(\mathrm{b})$.

${ }_{12}$ FATF 40 Recommendations, Recommendation 3. 
28Ibis of the Amended Protocol replicates the language in the AU Convention's money laundering provision, which itself strongly resembles the relevant provisions of the 1988 Vienna Convention, UNTOC and UNCAC. ${ }^{13}$ But, as will be discussed in Section 3.B, the Amended Protocol also departs from the current approach to criminalizing money laundering by narrowing the scope of the offence to the laundering of 'the proceeds of corruption and related offences' - an apparent reference to Article 28I on corruption. The Amended Protocol also points anti-money laundering enforcement efforts in a notably different direction by granting a regional court criminal jurisdiction over an offence that has always been prosecuted at the domestic level. In doing so, the drafters of the African Court could not draw upon or benefit from previous discussions among state officials about the potential wisdom or pitfalls of this shift because the negotiators of the Rome Statute barely contemplated the possibility of granting the ICC jurisdiction over money laundering.

While the negotiators of the Rome Statute debated the inclusion of transnational crimes like drug trafficking and terrorism at relatively great length, the possibility of including money laundering attracted very little attention. Some states apparently supported the inclusion of money laundering in the Rome Statute, and Nigeria even expressed this view orally at the Rome Conference. ${ }^{14}$ But the negotiators never seriously considered including money laundering in the Rome Statute, nor did they consider revisiting this issue at the Review Conference in Kampala in 2010. ${ }^{15}$ Given that the negotiators lacked sufficient time at the Rome Conference to settle higher-priority issues like the inclusion of drug trafficking and the definition of aggression, money laundering understandably received very little attention. ${ }^{16}$ As a result, the merits and drawbacks of prosecuting money laundering were never fully debated by states (or by NGOs and scholars) during the Rome Conference or before the inclusion of money laundering in the Amended Protocol of the African Court. At the Rome Conference, the limited amount of time available for negotiations appears to have precluded the inclusion of transnational crimes, such as drug trafficking and money laundering. By contrast, time

131988 Vienna Convention art. 3(1)(b); UNTOC art. 6; UNCAC art. 23; AU Convention art. 6.

14 A. Schloenhardt, "Transnational Organised Crime and the International Criminal Court: Towards Global Criminal Justice’ 24 University of Queensland Journal (2005) at 93, 120.

15 Ibid.

16 P. Robinson, 'The Missing Crimes' in A. Cassese et al. (ed) The Rome Statute of the International Criminal Court: A Commentary, Volume I (Oxford: Oxford University Press, 2002 ) at $497,506$. 
constraints appear to have had the opposite effect with respect to the drafting of the Amended Protocol - transnational crimes were included en masse, with seemingly little debate about the reasons or consequences.

Had there been such a debate among states during the drafting of either the Rome Statute or the Amended Protocol, then delegates might have discussed the potential benefits to prosecuting money laundering at international courts, as well as the serious jurisdictional and evidentiary problems that might arise. They might have noted, for example, that prosecutors could benefit from the ability to link economic crimes with the commission of other international and transnational crimes. Economic crimes such as corruption and money laundering can be among the structural causes of violence, and yet prosecutors at international criminal courts and tribunals lack jurisdiction over these types of systemic injustices. ${ }^{17}$ The same is true in the broader field of transitional justice, which has also tended to overlook economic crimes. ${ }^{18}$ Truth and reconciliation commissions, for instance, have typically focused on violence by the police, military and paramilitary that violates civil and political rights rather than non-violent economic crimes. ${ }^{19}$

Although international criminal courts and tribunals have not yet fully grappled with the factual and legal links between economic crimes and armed conflict, the connections are discernible and have been the subject of reports and newspaper articles, if not judgments. ${ }^{20}$ In Sierra Leone and Liberia, for instance, the former Liberian President Charles Taylor reportedly amassed a fortune through control over natural resources in the two states, including control over diamond areas, the iron ore industry, and timber as well as the Firestone rubber plantation in Liberia. ${ }^{21}$ The revenue generated through this illicit exploitation of natural resources is widely understood to have allowed Taylor to fund armed factions that perpetrated atrocities in Sierra Leone and fuelled conflict in the region. ${ }^{22}$ The SCSL trial judgment in the Taylor case is, however, primarily limited to findings about Taylor's receipt of rough diamonds from leaders of the Revolutionary United Front (RUF) in exchange for

17 R. Carranza, 'Plunder and Pain: Should Transitional Justice Engage with Corruption and Economic Crimes?' 2 International Journal of Transitional Justice (2008) at 310, 316-17.

18 ibid. at 319 .

19 Ibid.

${ }^{20}$ See e.g. P. R. Keefe, 'Buried Secrets: How an Israeli Billionaire Wrested Control of One of Africa’s Biggest Prizes' The New Yorker (8 July 2013).

${ }^{21}$ International Coalition for Justice, Following Taylor's Money: A Path of War and Destruction (2005), at 16 .

22 See e.g. D. Carvajal, 'Hunting for Liberia’s Missing Millions' The New York Times, (Monrovia, Liberia 30 May 2010). 
arms, ammunition, and other supplies. ${ }^{23}$ The Court also found that Taylor facilitated a relationship between a Belgian diamond dealer and a leader of the RUF, Issa Sesay, for the purpose of diamond transactions. ${ }^{24}$ But the trial judgment makes no further findings about what Taylor did with the diamonds and the wealth they generated. The judgment makes no mention of the fact that Taylor apparently sent money abroad, to bank accounts in Switzerland, Burkina Faso, and elsewhere. ${ }^{25}$ The judgment also makes no mention of Taylor's extensive use of false aliases or identities and shell companies, which seems to have been designed to enable him to launder the proceeds of crimes, namely revenue from the illicit extraction of natural resources. ${ }^{26}$

The charges in the Taylor indictment arguably generated little need for the trial chamber to go further in its findings about how Taylor funded the armed conflict. Nor would such findings have been feasible for the trial chamber on the basis of the evidence before them in this case, as the parties relied heavily on witness testimony rather than the type of documentary evidence that would be needed to demonstrate money laundering in the context of the diamond trade. But the problem of stolen assets did not escape the notice of the SCSL, as the Prosecutor did request 'all states concerned' to identify, locate, and freeze Taylor's assets in their territory. ${ }^{27}$ In July 2003, the Prosecutor met with some success in this respect, as the Swiss government complied with a request from the Prosecutor to freeze approximately US $\$ 1.5$ million in Swiss bank accounts held by two persons associated with Taylor. ${ }^{28}$

The Taylor case illustrates one of the advantages of conducting investigations into financial crimes alongside investigations of atrocities: the potential for asset recovery. While the investigations into Taylor's assets by the SCSL as well as the United Nations and the Liberian government have yet to meet with significant success or the repatriation of funds, such asset recovery efforts are typically very lengthy and could still yield a positive outcome for Liberia. In addition, money laundering investigations have the advantage of producing evidence about the commission of other crimes. Such investigations can play an important role in supporting investigations of other predicate crimes, the proceeds of which have

23 Trial Judgment, Prosecutor v Charles Ghankay Taylor (SCSL-03-o1-T), Trial Chamber II, 18 May 2012, $\iint 5843-6149$.

24 Ibid. at $\$ 6103$.

25 International Coalition for Justice supra note 21.

26 Ibid. at 7 .

27 Prosecutor $v$ Charles Ghankay Taylor, Warrant of Arrest and Order for Transfer and Detention, 7 March 2003, 3.

28 SCSL Office of the Prosecutor Press Release, ‘2 Million of Taylor’s Assets Frozen’ 23 July 2003 ( 2 million in Swiss Francs). 
been laundered. ${ }^{29}$ Money laundering investigations can provide critical evidence regarding where money originated, when it was received or deposited, and who the beneficiaries are. ${ }^{30}$ Though the Amended Protocol limits money laundering to the predicate offence of corruption, money laundering investigations at the African Court could still support charges of other crimes, even if money laundering itself could not necessarily be included in an indictment. Finally, investigations of money laundering by international prosecutors could potentially expose or bring attention to the roles played by foreign individuals, companies, and banks in armed conflicts and large-scale corruption in African states. Such exposure could even help to trigger or provide evidentiary support for domestic investigations in non-African states. ${ }^{31}$

\section{JURISDICTIONAL QUESTIONS}

Prosecutors at the African Court can expect to encounter a number of jurisdictional hurdles in attempting to try individuals or legal persons for the offence of money laundering under Article 28Ibis of the Amended Protocol. In an initial prosecution for money laundering, defence counsel would be likely to challenge the provision's compliance with the principle of nullum crimen sine lege, or the principle of legality. Even if judges were to find that the principle of legality poses no problems for the offence of money laundering, prosecutors may still find that the provision's limited scope or subject matter jurisdiction prevents frequent reliance on it. In addition, the possible preconditions for the exercise of jurisdiction, as set out under Article $46 \mathrm{E} b i s$ of the Amended Protocol, are also likely to be limited.

\section{A. The Principle of Nullum Crimen Sine Lege}

Given that the African Court would be the first international criminal court to exercise jurisdiction over money laundering, defence counsel can be expected to challenge the legality of the Court's jurisdiction on the basis of the principle of nullum crimen sine lege. Defence counsel might argue, for example, that the African Court lacks jurisdiction over money laundering because the offence has not been criminalized under international law, customary or conventional. A number of international treaties include provisions on money

29 Financial Action Task Force, Operational Issues: Financial Investigations Guidance, June 2012, $\$ 23$.

30 Ibid.

${ }^{1}$ S. Starr, 'Extraordinary Crimes at Ordinary Times: International Justice Beyond Crisis Situations' 101 Northwestern University Law Review (2007) at 1257, 1287-8. 
laundering (e.g. the 1988 Vienna Convention and UNTOC), but these treaties do not enjoy universal participation among African states and cannot be viewed as evidence of custom, for reasons explained below. Moreover, these treaties also do not, by themselves, create international criminal responsibility, as they only require states to criminalize money laundering under domestic, as opposed to international law.

But prosecutors should be able to overcome jurisdictional challenges based on the principle of legality by arguing that Article 28Ibis not only sets out the Court's subject matter jurisdiction, but also provides the applicable law. ${ }^{32}$ In other words, this provision is both jurisdictional and substantive. This would not be a novel legal argument. In fact, scholars have made the same arguments about Articles 6, 7, 8, and 8bis of the Rome Statute of the ICC, which respectively concern genocide, crimes against humanity, war crimes, and aggression. 33 These provisions do not entirely conform with customary international law. But because the articles themselves criminalize the crimes over which the Court enjoys jurisdiction and they only apply prospectively, the principle of nullum crimen sine lege does not pose problems. This approach to the Rome Statute is supported by Article 21 concerning applicable law. This provision requires the Court to apply the Statute 'in the first place', along with the Elements of Crimes and the Rules of Evidence, before applying in the second place' custom or treaty law. Unlike the Rome Statute, the Amended Protocol does not contain any provision on applicable law. But the absence of such a provision would not preclude arguments that the provisions on the international criminal jurisdiction of the African Court effectively conflate jurisdiction and applicable law.

Interpreting Article 28I bis of the Amended Protocol as a substantive provision is, in fact, the only workable approach to the offence of money laundering. If prosecuting money laundering at the African Court is to be viable in practice, then the provision itself must be understood as stating the applicable law because of the absence of any customary international law prohibiting money laundering. The existence of numerous treaty provisions that require the criminalization of money laundering does not evidence the existence of a parallel customary norm, despite the fact that some of these treaties enjoy high ratification levels. While state practice in criminalizing money laundering may be widespread, this practice appears to stem, at least in part, from states'

${ }^{32}$ R. O'Keefe, International Criminal Law (Oxford: Oxford University Press, 2015) at s14.59.

33 Ibid.; M. Milanovic, 'Is the Rome Statute Binding on Individuals? (And Why We Should Care)' 9 Journal of International Criminal Justice (2011) at 25; but see N. Boister, 'Treaty Crimes, International Criminal Court?' New Criminal Law Review (2009) at 341, 347-8. 
treaty obligations, and not from a freestanding sense of legal obligation to do so, which would be required for the requisite opinio juris. In addition, the 40 Recommendations on money laundering and terrorist financing issued by the FATF also cannot be taken as evidence of a customary norm prohibiting money laundering. The FATF 40 Recommendations comprise a non-binding instrument. Compliance with the anti-money laundering norms set out in the Recommendations reveals nothing about whether states have a freestanding sense of legal obligation. Instead, FATF has brought about widespread implementation of anti-money laundering laws through political and economic pressure, and by encouraging states to comply with their existing treaty obligations under the 1988 Vienna Convention and UNTOC.

The absence of a customary prohibition on money laundering is, in essence, irrelevant for the jurisdiction of the African Court. When drafting the constituent instrument of a judicial institution such as the African Court, states may vest it with whatever jurisdiction they choose, and they can also authorize it to apply any law of their choosing (subject to the principle of legality). ${ }^{34}$ The subject matter jurisdiction and applicable law of international courts and tribunals do not necessarily depend on existing customary or treaty law, but may be determined by the constituent instrument itself. Nor must the subject matter jurisdiction of international criminal courts be limited to serious or grave crimes - a category into which offences like corruption and money laundering may or may not fall, depending partly on how we understand terms like serious and grave. ${ }^{35}$ While the ICC is indeed limited to 'the most serious crimes of international concern,' this may be understood as a policy decision made by the drafters of the Rome Statute, and not as the consequence of any legal requirement. ${ }^{36}$

As a result of the fact that the Amended Protocol not only establishes jurisdiction over money laundering but also sets forth the applicable law, it may be understood as a treaty that creates international legal obligations for individuals. While treaties that directly impose obligations on individuals or legal persons are relatively rare in the international legal system, they are not unheard of (see e.g. the 1949 Geneva Conventions). ${ }^{37}$ But in order to avoid binding individuals or legal persons in states that did not consent to the Amended Protocol, the jurisdictional scope of the money laundering

34 O'Keefe supra note 32, at s2.15.

35 But see A. Abass, 'Prosecuting International Crimes in Africa: Rationale, Prospects and Challenges' (2013) 24 European Journal of International Law (2013) 339-940, at 933.

${ }^{6}$ Rome Statute art. 1.

37 Milanovic supra note $33,46-7$. 
provision would have to be limited in practice to offences that occurred on the territory of states parties, or offences committed by the nationals of states parties. $^{3^{8}}$ The exercise of jurisdiction over offences committed by nonnationals outside of the territory of states parties to the Amended Protocol would therefore run afoul of the principle of legality. ${ }^{39}$

This approach to the Amended Protocol, as a substantive as well as jurisdictional provision, is workable due to the fact that Article $28 \mathrm{I}$ bis is relatively detailed. This provision closely resembles the money laundering provision in the 1988 Vienna Convention, which has formed the basis for all subsequent treaty provisions on money laundering. These treaty provisions are not necessarily less detailed than domestic statutory provisions on money laundering, and they could form a sufficient basis for giving individuals and legal entities notice of the actus reus, or the conduct that constitutes a criminal offence. This approach to Article 28I bis is also viable because the temporal jurisdiction of the African Court is not retroactive. ${ }^{40}$ If the applicable law set out in Article 28I bis could apply retroactively, then this would indeed pose a problem with respect to the principle of legality.

Finally, Article 28I bis does, however, fail to stipulate a mens rea requirement in its chapeau, unlike the 1988 Vienna Convention, UNTOC, and UNCAC, which all require states parties to criminalize conduct that was 'committed intentionally'. The omission of a mens rea requirement could prove problematic from the perspective of the principle of legality, unless prosecutors and judges at the African Court engage in some creative treaty interpretation. The use of the word 'knowing' in Article 28Ibis(i) and the phrase 'with the knowledge' in Article 28Ibis(ii) could, for instance, be taken as indications that the conduct set out in this provision must be committed intentionally. But if such arguments fail to persuade the judges, then this apparent drafting error - which also plagues the other transnational criminal law provisions - could indeed prevent the prosecution of money laundering, along with many other offences set out in the Amended Protocol.

\section{B. The Scope of the Court's Jurisdiction over the Offence of Money Laundering}

Assuming that the principle of legality would not pose an insurmountable problem for prosecutors at the African Court with respect to the offence of

\footnotetext{
$3^{8}$ Amended Protocol art. 46E bis(2)(a), (b).

39 Ibid., art. $46 \mathrm{E}$ bis $(2)(\mathrm{c}),(\mathrm{d})$.

$4^{\circ}$ Ibid., art. $46 \mathrm{E}(1)$.
} 
money laundering, the scope of the offence set out in the Amended Protocol would nevertheless limit the provision's practical application. The offence of money laundering, as it appears in the Amended Protocol, is more limited than the offence as it appears in the more recent universal treaties, UNTOC and UNCAC, because it designates only 'corruption or related offences' as predicate offences. The term predicate offence refers to an offence that generates proceeds that may become the subject of a money laundering offence. ${ }^{41}$ Both UNTOC and UNCAC contain money laundering provisions that refer broadly to 'the proceeds of crime', without imposing limits on the type of crime..$^{42}$ The Amended Protocol, by contrast, adopts the approach of the AU Convention, which limits the predicate offence to 'corruption or related offences'. ${ }^{43}$ By confining the predicate offences to corruption or related offences, as opposed to criminal offences generally, the Amended Protocol greatly restricts the applicable scope of Article 28Ibis. In addition, the meaning of 'related offences' is uncertain in the context of both the Amended Protocol and the AU Convention, although it may be understood, at least in part, as a reference to crimes such as the use or concealment of proceeds derived from acts of corruption. ${ }^{44}$

In restricting the predicate offences for money laundering in this manner, the Amended Protocol not only departs from UNTOC and UNCAC, but it also runs contrary to the FATF 40 Recommendations. FATF Recommendation 3 indicates that states 'should apply the crime of money laundering to all serious offences, with a view to including the widest range of predicate offences'. An interpretive note further explains that states may describe predicate offences as 'all offences', or by reference to a list of predicate offences or a particular threshold, such as serious offences or offences that attract a certain penalty. ${ }^{45}$ Without a drafting history for the Amended Protocol, it is difficult to appreciate what might have inspired this decision to limit money laundering to proceeds derived from corruption or related offences. From a policy perspective, it is also difficult to justify the limited scope of Art 28Ibis in light of the well-known links between money laundering and the other international and transnational crimes set out in the Amended Protocol, such as war crimes and crimes against humanity, piracy, terrorism, drug trafficking, human trafficking, and the illicit exploitation of natural resources. As noted in

${ }^{41}$ UNTOC art.. 2(h).

$4^{2}$ Ibid., art. 6; UNCAC art. 23.

43 Amended Protocol art. 28Ibis(1)(i).

44 Ibid., art. 28I(1)(h); AU Convention, art. 4(h).

45 FATF, The FATF Recommendations: International Standards on Combating Money Laundering and the Financing of Terrorism \& Proliferation, February 2012, at 34. 
Section 2 of this chapter, for example, money laundering has been linked to the illicit exploitation of natural resources in both Sierra Leone and the DRC. Yet laundering the proceeds of such illicit exploitation would fall outside of the scope of Article $28 \mathrm{I}$ bis.

It is also difficult to appreciate why the drafters decided to conclude Article 28Ibis with a safeguard clause which provides that " $[\mathrm{n}]$ othing in this article shall be interpreted as prejudicing the power of the Court to make a determination as to the seriousness of any act or offence'. ${ }^{6}$ This provision would be logical if this Article described predicate offences by reference to a threshold of seriousness. Given that sub-paragraph 1 defines predicate offences not as serious offences, but as corruption or related offences, it is unclear why the African Court would have an interest in safeguarding its authority to determine the 'seriousness of any act or offence'. Because the Amended Protocol limits predicate offences to 'corruption or related offences', this clause appears to be overbroad in preserving the Court's power to make threshold determinations as to the seriousness of 'any act or offence'.

Sub-paragraph 2 of Article 28Ibis would have been easier to explain if it had preserved the African Court's authority to determine what qualifies as a serious corruption offence. Article 28I, which concerns corruption, limits the scope of corruption offences to acts 'of a serious nature affecting the stability of a state, region or the Union'. ${ }^{47}$ This clause has no origins in other international or regional anti-corruption treaties. Nor does similar qualifying language appear in any of the other transnational criminal law provisions in the Amended Protocol, except for the offence of illicit exploitation of natural resources, set out in Article 28Lbis. ${ }^{48}$ The terms 'serious', 'stability' and 'region' are undefined and open to debate, and therefore likely to result in preliminary challenges by those accused of corruption. ${ }^{49}$ For unknown reasons, the drafters of the Amended Protocol apparently considered it necessary to limit the scope of only the corruption offences and the offence of illicit exploitation of natural resources. None of the other transnational criminal law offences, which could also result in prosecutions of relatively minor infractions as well as more major violations, have a seriousness threshold. Perhaps, in the eyes of

$4^{6}$ Art. 28Ibis(2).

47 Amended Protocol art. 28I(1). See also J. Hatchard's discussion of this phrase in 'Combating Corruption Effectively? The Role of the African Court of Justice and Human Rights' in the same volume, Section 3 A.

$4^{8}$ For a discussion of this phrase in the context of the offence of illicit exploitation of natural resources see D. Dam and J. G. Stewart, 'Illicit Exploitation of Natural Resources' in the same volume, Section 1.

49 Ibid. 
the drafters, any violations, however minor, of the other transnational criminal law offences would potentially be suitable for prosecution by the African Court, while this would not be the case for instances of petty corruption, for example. Alternatively, the drafters may have had concerns about giving the Prosecution unfettered discretion to bring corruption charges in particular. But without travaux préparatoires for the Amended Protocol, these possible explanations remain speculative.

The inclusion of a seriousness threshold for corruption and illicit exploitation of natural resources, but not for any of the other transnational crimes, is questionable. In light of the sheer frequency with which crimes like drug trafficking and trafficking in persons are committed in Africa, the other provisions covering transnational crimes arguably could have also benefited from a threshold of some sort. During the drafting of the Rome Statute, by contrast, concerns about flooding the ICC with the prosecution of offences like drug trafficking led, in part, to exclusion of transnational crimes from the Rome Statute..$^{\circ}$ In addition, the prosecution of the remaining four offences war crimes, crimes against humanity, genocide, and aggression - is limited to 'the most serious crimes of concern to the international community as a whole'. Regardless of the reasons why the drafters limited the African Court's jurisdiction over corruption, the effect is to limit the Court's jurisdiction over money laundering as well as corruption, as the scope of the money laundering provision depends in part on the scope of its predicate offence, corruption.

\section{Application of Jurisdictional Preconditions to the Offence of Money Laundering}

The African Court's exercise of jurisdiction over the offence of money laundering would also be limited by the fact that only two out of the four general preconditions for the Court's exercise of jurisdiction, set out in Article $46 \mathrm{E} b i s$, would apply to this offence. Article $46 \mathrm{E} b i s(2)$, which suffers from its own drafting problems, appears to provide for the exercise of jurisdiction by the African Court on the basis of (a) territoriality, (b) active personality, (c) passive personality, and (d) the protective principle, which covers extraterritorial acts that threaten a vital interest of a state party. ${ }^{51}$ Though Article $46 \mathrm{Ebis}(2)$

50 Preparatory Committee on the Establishment of an International Criminal Court, Summary of the Proceedings of the Preparatory Committee during the Period 25 March-12 April 1996, $\int 72$.

${ }^{51}$ For a discussion of the drafting problems see V. Nerlich, 'Preconditions to the Exercise of Jurisdiction (Article 46Ebis), Exercise of Jurisdiction (Article 46F) and the Prosecutor (Article 46G)' in G. Werle and M. Vormbaum (eds), The African Criminal Court: A Commentary on the Malabo Protocol (Asser Press, 2016). 
curiously omits any reference to states parties, it appears that this provision is meant to provide for the Court's exercise of jurisdiction over crimes committed on the territory of a state party and by a national of a state party, in addition to crimes that victimize the nationals of a state party or threaten the vital interests of a state party. ${ }^{52}$ In the case of money laundering, however, only the territoriality and active personality principles are applicable.

The protective principle is inapplicable in the money laundering context on account of the principle of legality. As mentioned above, the principle of nullum crimen sine lege would be violated by the application of Article 28Ibis to nationals of non-states parties for acts committed outside of the territory of a state party to the Amended Protocol. Because the Amended Protocol sets out the substantive law on money laundering (in the absence of customary law), the Court's exercise of jurisdiction is limited to conduct that takes place on the territory of a state party, and/or by one of its nationals. As a consequence, extraterritorial acts of money laundering by non-nationals fall outside of the jurisdiction of the Court, even where they threaten a vital interest of a state party. ${ }^{53}$

In addition, the jurisdictional precondition based on the protective principle, or the nationality of the victim of the crime, would also be of little relevance in the case of money laundering. Article $46 \mathrm{Ebis}(2)(\mathrm{c})$ provides that the Court may exercise jurisdiction 'when the victim of the crime is a national' of a state party. The commission of many of the offences set out in the Amended Protocol would produce identifiable victims, such as trafficked persons, the crew or passengers detained by pirates, and persons killed or injured by acts of terrorism. In the case of money laundering, however, identifying victims would be a difficult, if not impossible task in many instances. This is not to argue that money laundering is a 'victimless crime'. Rather, the identification of victims or persons affected by the offence of money laundering is not a straightforward or even feasible task, as it might be in the case of crimes involving death or injury, for example.

In seeking to identify the victims of an act of money laundering, the African Court would have to identify the victims of the predicate offence of corruption or related offences. While disposing of the proceeds of crime may not, in itself, produce victims, the predicate crime of corruption may indeed cause harm to persons or legal entities. But acts of corruption 'of a serious nature affecting the stability of a state, region or the Union' are likely to generate an exceptionally wide range of potential victims. Acts of corruption that would actually have such an impact on stability (whether political, economic, legal, etc.) are

$5^{2}$ Ibid.

53 Amended Protocol art. $46 \mathrm{E} b i s(2)(\mathrm{d})$. 
likely to have innumerable victims among the population of a state, region, or the African continent. Corrupt conduct that entails such consequences is inherently unlikely to have affected a discrete number of persons who may be identified by the African Court for jurisdictional purposes. Even if this were the case, difficult questions might arise as to who or what ought to qualify as a victim in the first place (a term that the Amended Protocol does not define). In light of these conceptual challenges, the jurisdictional precondition based on the nationality of the victim is likely to be unworkable in the context of the money laundering offence, limited as it is to predicate crimes involving corrupt acts (or related offences) of a serious nature.

The jurisdictional preconditions for money laundering would therefore be limited to acts on the territory of a state party, and acts by a national of a state party. ${ }^{54}$ The full scope of the African Court's territorial jurisdiction may, however, still be an open question in the context of money laundering. Would acts of money laundering that are begun in a state party and completed in a non-state party such as Switzerland, fall under the scope of its territorial jurisdiction? Such an interpretation would give the African Court a significantly greater capacity to prosecute money laundering, which is likely to involve cross border transactions in which money flows from Africa to international banking centres outside of Africa.

\section{EVIDENTIARY CHALLENGES}

If prosecutors were to surmount the potential jurisdictional hurdles described in Section 3, then another set of evidentiary challenges might await. This Section focuses on two challenges in particular: the complexities of financial investigations from an evidentiary perspective, and the African Court's likely dependence on cooperation from non-state parties as well as private sector entities.

\section{A. Complex Financial Investigations}

Financial investigations, of the sort that would be necessary to bring charges of corruption and money laundering, would be quite distinct from the types of investigations that are typically required for cases involving crimes against humanity, etc. At the modern international criminal courts and tribunals, post Nuremberg, witness testimony has been dominant, in good part because

54 Amended Protocol, art. 46Ebis(2)(a), (b). 
documentary evidence of atrocities has often not been readily available. 55 The accused who appeared before the International Criminal Tribunals for the former Yugoslavia and Rwanda, for example, did not keep the sort of meticulous documentary records that the Nazis did during the Holocaust. But investigations of acts of corruption and money laundering would require prosecutors at the African Court to focus on documentary evidence to a much greater extent than has been the case at modern international criminal courts and tribunals to date. While witness testimony could feature in trials for corruption and money laundering at the African Court, such testimony is likely to play a lesser, secondary role as compared with trials at the ad hoc tribunals, for instance.

Furthermore, financial investigations involving transactional forensics are likely to be exceptionally data intensive. ${ }^{56}$ In order to identify and document the movement of money, future prosecutors and investigators at the African Court should expect to draw on bank account statements, wire transfer records, financial statements, tax records, customs records, etc. ${ }^{57}$ Complex financial investigations require lawyers to work together with professionals from other fields, including financial investigators, forensic accountants, and forensic computer specialists. ${ }^{8}$ A multidisciplinary investigation team would likely be necessary, and it would undoubtedly be expensive. Many commentators have already noted that the range of transnational crimes included within the jurisdiction of the African Court will increase its operating costs. ${ }^{59}$ This is likely to be especially true for the types of financial investigations needed to support prosecutions for money laundering. Such investigations are likely to be highly resource intensive in terms of both required personnel and funding. Should the Court struggle financially, as have its predecessor institutions, complex financial investigations would likely be quite burdensome for this institution.

\section{B. Cooperation with States and Private Actors}

Even if prosecutors and investigators at the African Court possessed the necessary budget and staff for conducting financial investigations, the type of

55 N. Combs, Fact-Finding without the Facts: The Uncertain Evidentiary Foundations of International Criminal Convictions (Cambridge: Cambridge University Press, 2010) at 12.

${ }_{56}$ Financial Action Task Force, Operational Issues: Financial Investigations Guidance, June 2012, $\$ 23$.

57 Ibid. at $\int \mathbb{\int} 27-8$.

$5^{8}$ Ibid.

59 M. Du Plessis, 'Implications of the AU Decision to Give the African Court Jurisdiction over International Crimes', Institute for Security Studies No. 234, June 2012, 9-10. 
evidence needed for prosecuting money laundering still might not be forthcoming. As with financial investigations at the domestic level, investigators at the African Court would need to be able to compel the production of evidence. ${ }^{60}$ But in contrast with courts and prosecutors in domestic legal systems, the African Court lacks the capacity to directly compel banks or other private institutions to produce documentary evidence. Like all international courts and tribunals, the African Court would be dependent on cooperation from states and also international organizations like the United Nations. But state cooperation would be particularly important for financial investigations because the African Court would depend on states not only to produce government documents such as tax or customs records, but also to act as intermediaries between the Court and private actors. The African Court would depend on states to order private entities to produce evidence such as bank account statements and wire transfers. ${ }^{61}$

The Amended Protocol accordingly provides for cooperation by states with the African Court, but these provisions are likely to leave the Court heavily dependent on the good will of non-African states that would not (and could not) be parties to the Amended Protocol. The Amended Protocol would, for example, require states parties to cooperate with the African Court with respect to requests for assistance and orders for the production of evidence and also the freezing of assets for the purpose of eventual forfeiture. ${ }^{62}$ But the African Court could not compel non-states parties to cooperate with it. Instead, the Court would only be entitled to seek, rather than compel, cooperation by non-state parties as well as regional or international courts and partners of the African Union. ${ }^{63}$ Given that states must consent to the jurisdiction of international courts and tribunals, it could not, of course, be otherwise. The Court could nevertheless seek to build a system for cooperation with non-state parties by concluding separate cooperation agreements

6o FATF supra note $56, \mathbb{} 75$.

${ }_{61}$ This predicament arose, for example, in The Prosecutor v Uhuru Muigai Kenyatta, where the Prosecution requested three years of the accused's bank records. See Decision on Prosecution's application for a finding of non-compliance under Article 87(7) of the Statute (ICC-o1/og/oz/11), 3 December 2014, \&33. The Kenyan government did not take steps to compel the production of bank records or facilitate a meeting between the Prosecution and relevant bank officials. Ibid. \$66. The Trial Chamber considered that the Kenyan Government's failure to provide all of the requested bank records, 'or to take steps to do so, fell below the standard of good faith cooperation required from States Parties'. Ibid. $\int 67$. The Prosecution dropped the charges in this case on 5 December 2014 due to lack of evidence and the Trial Chamber terminated the proceedings on 13 March 2015.

62 Amended Protocol, art. 46L(2)(b), (f).

63 Ibid. at art. $46 \mathrm{~L}(3)$. 
with them, to the extent possible. ${ }^{64}$ Unlike the ICC, however, the African Court would lack the ability to seek assistance from the UN Security Council, which has the capacity to impose cooperation obligations on UN members that are non-state parties to the Rome Statute. ${ }^{65}$ The Amended Protocol makes no mention of cooperation directly with non-state actors such as banks, as all such cooperation would be ordered by states themselves.

Due to the structure of the international banking system, financial investigations in money laundering cases would likely strain the African Court's cooperation regime, as the Court would probably find itself most in need of cooperation by non-states parties. Much money laundering in Africa is undoubtedly confined to the continent, and thus to potential states parties to the Amended Protocol. But the type of corruption and money laundering cases that would fall within the African Court's jurisdiction would likely involve banks in major western financial centres in non-states parties, especially in nonstates parties with bank secrecy laws that are favourable to money launderers. In confining the Court's jurisdiction over corruption and money laundering cases to serious corruption that affects the stability of a state, region or the African Union, the Amended Protocol brings to mind instances of heads of state and other high-level officials who have laundered embezzled state funds through Swiss bank accounts and through the purchase of luxury real estate in Paris, Miami or New York. ${ }^{66}$ In other words, corruption and money laundering of the requisite severity is very likely to have a significant extraterritorial component that would necessitate cooperation with non-state parties.

The African Court's success in securing the cooperation of non-state parties, whether on an ad hoc basis or through permanent cooperation agreements, could depend in part on the extent to which those non-states parties were pursuing their own investigations of the same or related conduct. While parallel domestic investigations could, in theory, facilitate cooperation between states and the African Court, in practice, states might instead view international investigations as potential disruptions to domestic law enforcement efforts. It may be expected that some non-state parties could prove unwilling or highly reluctant to cooperate with investigations by the African Court that could interfere with long-standing, carefully designed domestic investigations. The same concerns actually formed the basis for some of the

64 Ibid. at art. $46 \mathrm{~L}(3)$.

65 O'Keefe, supra note 32 , at s14.86.

66 See e.g. L. Story and S. Saul, 'Stream of Foreign Wealth Flows to Elite New York Real Estate' The New York Times (7 February 2015). 
objections that were raised by states regarding the inclusion of transnational crimes like drug trafficking and terrorism in the Rome Statute.

The United States, for example, expressed concerns about how the prosecution of drug traffickers and terrorists by the ICC would interfere with and undermine investigations undertaken by the United States, often in cooperation with other states. ${ }^{67}$ The United States described its own investigations as highly sophisticated, costly, wide ranging, and long-term (often spanning many years). These investigations are geared towards prevention as well as prosecution, and tend to involve sensitive and confidential information. The United States considered that the integrity of such domestic investigations could be undermined by ICC investigations and prosecutions, which are typically more limited and not concerned with prevention. The United States feared that ICC investigators might make different decisions about who and when to apprehend, and could also compromise sources of intelligence.

The same types of concerns could also be expected in the context of investigations and prosecutions at the African Court with respect to economic crimes such as corruption and money laundering. FATF has specifically noted that in domestic settings, investigators should make timely use of search warrants in order to seize documentary evidence or electronic data so as to minimize opportunities for suspects to destroy information. ${ }^{68}$ Poor coordination of corruption and money laundering investigations by the African Court and by domestic jurisdictions could conceivably result in suspects purging records or destroying evidence. In such circumstances, non-states parties would likely decline to cooperate altogether, or would cooperate only after carrying out domestic investigations. The timing of investigations and prosecutions by the African Court for corruption and money laundering may therefore be heavily dependent on the timing of domestic investigations. The two could potentially be complementary if domestic law enforcement efforts were to result in the freezing and seizure of assets while a parallel case at the African Court were to result in individual criminal liability. The African Court could potentially stand to benefit from domestic enforcement actions in non-state Parties, as long as it is willing to wait for the initiation or even completion of domestic proceedings which unearth evidence and identify assets. The African Court could, however, find itself somewhat dependent on domestic investigators pursuing timely enforcement actions in the first place, while the relevant evidence still exists.

67 Comments Received Pursuant to Paragraph 4 of General Assembly Resolution 49/53 of the Establishment of an International Criminal Court, UN Doc. A/AC.244/1/Add.2, 31 March 1995.

68 FATF supra note $56, \mathbb{1} 78$. 
It is also conceivable, however, that such timing problems might never arise on account of the provision for immunity in Article 46Abis. The Amended Protocol's controversial immunity provision precludes the prosecution of heads of state or government ('or anybody acting or entitled to act in such capacity, or other senior state officials based on their functions') during their tenure of office. ${ }^{69}$ This provision is quite likely to result in the delay of prosecutions of money laundering because the predicate crime of corruption or related offences is limited to acts 'of a serious nature affecting the stability of a state, region or the Union'. Corruption of this magnitude necessarily tends to involve high-level government officials who would fall within the scope of Article $46 \mathrm{Abis}$, and would thus be protected from prosecution for the duration of their time in office. In practice, whether this immunity provision would merely delay prosecutions of government officials, or effectively render them impossible, remains to be seen. In the meantime, private individuals could, of course, still be prosecuted for the laundering of funds derived from private sector corruption - assuming that such conduct would reach the seriousness threshold of the corruption provision. ${ }^{70}$

\section{ASSET RECOVERY AND REPARATIONS}

From the perspective of reparations for victims and the repatriation of stolen assets, the inclusion of the offence of money laundering in the jurisdiction of the African Court is innovative and could, at least in theory, facilitate the Court's ability to carry out this aspect of its mandate. Article 45 of the Amended Protocol provides that the Court 'may make an order directly against a convicted person specifying appropriate reparations to, or in respect of, victims, including restitution, compensation and rehabilitation'. ${ }^{71}$ This provision depends on the Court's ability to seize or bring about the transfer of assets of convicted persons. Article 43 of the Amended Protocol accordingly provides that 'the Court may order the forfeiture of any property, proceeds or any asset acquired unlawfully or by criminal conduct, and their return to their rightful owner or to an appropriate Member State'. ${ }^{72}$ In reality, these provisions may not function as intended, and the Court may instead need to rely on

69 See D. Tladi, 'Immunities', in G. Werle and M. Vormbaum (eds), The African Criminal Court: A Commentary on the Malabo Protocol (The Hague: Asser Press, 2016); Amnesty International, Malabo Protocol: Legal and Institutional Implications of the Merged and Expanded African Court (2016), 26-7.

70 See Hatchard, supra note 47 .

${ }^{71}$ Amended Protocol art. 45(2).

$7^{2}$ Ibid. at $43 \mathrm{~A}(5)$. 
money laundering investigations in order to locate assets and request domestic jurisdictions to order freezing, seizure, and confiscation.

As trials at other international criminal courts and tribunals have shown, accused may not cooperate with orders by the African Court for the forfeiture of property, proceeds or assets acquired by criminal conduct. In fact, accused persons may claim indigence while having actually hidden vast wealth abroad, in overseas bank accounts under other names, for example. The prosecution of Charles Taylor by the SCSL raised just this problem, as Taylor received legal aid from the SCSL, while the SCSL attempted to trace his assets. Thus, forfeiture orders by the African Court under Article 43 may be wholly ineffective, and it may instead be necessary to rely on cooperating states to freeze the bank accounts of accused persons while the prosecution is ongoing. Following a conviction, the African Court could potentially reach agreements for the provision of reparations or the repatriation of funds to an African Union member state, but this would have to be arranged on a case-by-case basis between the African Court, the cooperating state, and potentially also the member state (if the state itself were the recipient of the repatriated funds).

Financial investigations that focus on money laundering could, in fact, play a significant role in helping the African Court to identify assets of accused persons that may be used for reparations should they be convicted. Money laundering investigations could potentially play a supporting role in cases involving a range of offences, from war crimes and crimes against humanity, to drug trafficking and terrorism. The narrow subject matter of the offence of money laundering, as set out in the Amended Protocol, may preclude convictions linked to predicate crimes beyond acts of corruption, but money laundering investigations by the African Court need not lead to criminal charges. The Court could perhaps conduct investigations of money laundering linked to other predicate offences, with a view to identifying assets rather than supporting a prosecution for money laundering. The ICC, for example, has conducted financial investigations in a number of its cases despite lacking the capacity to bring criminal charges for such conduct. Money laundering investigations thus have the potential to play an important role in facilitating reparations for victims, beyond cases involving corruption.

\section{CONCLUSION}

Almost all of the potential obstacles to prosecuting money laundering at the African Court could ultimately be resolvable, apart from the inherently limited scope of the offence as stipulated in the Amended Protocol. Arguments about the principle of nullum crimen sine lege could be defeated on the 
basis that the Amended Protocol itself provides the applicable law, and does so only on a prospective basis. The text of Article 28Ibis of the Amended Protocol thus alleviates the need to prove the existence of a separate customary prohibition on money laundering, which would not be a fruitful exercise. In addition, the jurisdictional preconditions that would be available to the African Court in situations involving money laundering would be limited, but still workable. The African Court's capacity to exercise personal jurisdiction over extraterritorial acts by non-nationals which threaten the vital interests of the state would run contrary to the principle of nullum crimen sine lege, and must be discarded as a possibility. Likewise, the African Court's ability to exercise jurisdiction over victims with the nationality of a state party is hard to reconcile with the realities of money laundering and serious acts of corruption, which typically lack clearly identifiable victims. But the African Court could still exercise jurisdiction over nationals of a state party, as well as crimes committed on the territory of a state party. The options available to the African Court are thus limited to those of the ICC - a workable outcome. ${ }^{73}$

The African Court could also face a number of evidentiary challenges, but these too are surmountable, at least in theory if not in practice. With enough funding and appropriate expertise, investigators at the African Court would be capable of carrying out the types of complex financial investigations needed to obtain evidence of money laundering as well as corruption. But the potential evidentiary obstacles go beyond the availability of financial and human resources, as the African Court also does not have the legal authority to impose cooperation obligations on non-states parties. Yet, the cooperation of nonstates parties may be especially important for prosecutions of money laundering because most major financial centres lie outside of Africa. While nonstates parties may be hesitant, and cooperation will most likely not be forthcoming in some instances, it is conceivable that given the right timing and political circumstances, the African Court could secure the cooperation of non-state parties.

By contrast, the last remaining obstacle may be inescapable, that is, the Amended Protocol's restrictive definition of the predicate crimes for money laundering. Instead of including all serious crimes within the scope of the predicate offences for money laundering, or all crimes included in the Amended Protocol, Article 28I bis inexplicably limits the predicate offences to the proceeds of serious acts of corruption. Without a drafting history, it is impossible to know why the Amended Protocol departs from the money

73 Rome Statute, art. 12(2). 
laundering provisions of the 1988 Vienna Convention, UNTOC, and UNCAC. The narrowness of the money laundering provision included in the Amended Protocol will form an obstacle to frequent reliance on this provision by prosecutors. In fact, money laundering charges may be rare given the further narrowness of its predicate crime, corruption. This obstacle will not prevent prosecutions for money laundering, but it will make them very unlikely. The drafters thereby relegated money laundering to a peripheral role in prosecutions at the African Court, which is unfortunate given that economic crimes can be among the structural causes of armed conflict, as prosecutors at the ICC have already discovered. 